\title{
THE COSTS AND COSTING OF NETWORKED LEARNING
}

\author{
Greville Rumble \\ Professor of Distance Education Management \\ The Open University \\ Walton \\ Milton Keynes, MK7 6AA \\ United Kingdom \\ Phone: +44 (0)1825 713291 \\ g.rumble@open.ac.uk; greville.rumble@btinternet.com
}

\begin{abstract}
The development of networked learning and the increasing development of online courses by both traditional and distance education institutions has raised many questions concerning the costs of online learning relative to both face-to-face teaching and other approaches to distance education. Additionally, attention has turned to the problem of costing networked learning, though as yet little progress has been made. This paper discusses both the emerging evidence on the costs of networked learning, relative to other forms of education, and its costing.
\end{abstract}

\section{KEY WORDS}

Networked Learning, Online Education, Distance Education, Economics, Costs, Costing

\section{INTRODUCTION}

Until the late 1950s there was relatively little interest in the costs of education, and virtually none in the costs of educational technology. This failure reflected the fact that innovation in teaching methods was a largely marginal activity: as one early analyst put it, 'education's technology, by and large, has made surprisingly little progress beyond the handicraft stage' [1 (p.7)]. However, the rising demand for and escalating costs of education led to attempts within the newly developing sub-discipline of the economics of education to quantify both the efficiency of public expenditure on education, and the economic benefits of providing it [2,3]. Educational technology came to be seen as a way of improving the efficiency of education through productivity increases. As a result analysts began to research into the costing of educational technology and the actual costs of distance education systems (for a fuller account of this work, see [4]).

Much of the early work undertaken under the auspices of the World Bank, UNESCO and USAID focused on the costs and cost structures of educational broadcasting projects [5, 6, 7, 8]. Within the UK other experts focused on the costs of using educational technology either for distance teaching or as a substitute for classroom teaching on campus $[9,10,11,12]$. Some of this work was developed further in Australia within the context of universities mixing traditional and distance education approaches $[13,14]$.

The development of networked learning has once again raised similar questions as policy makers and analysts ask both whether networked learning is cheaper or more expensive than other approaches to education, and what needs to be taken into account in costing such systems. 


\section{FRAMEWORKS FOR COSTING}

The key to much of the early work lies in the attempt to identify clearly the nature of the costs involved, and what drives them, so that not only can all the relevant costs be taken into account, but also their behavior within planned or actual systems can be modelled.

So far as the nature of the costs are concerned, most studies adopt the conventional distinction between capital costs (buildings, equipment and furniture) which are annualized over their expected life, and revenue costs. The latter are normally categorized as staffing costs (including on-costs) and non-staffing costs (covering revenue expenditures on premises, stocks, supplies, consumables, and expenses). Generally capital costs have been regarded as non-recurrent costs - though the short life of some capital items, particularly in the IT area, means that institutions are increasingly treating such budgets as a recurrent item that is treated in much the same way as revenue budgets are. On the other hand, revenue expenditure on the development of course materials (which involves considerable expenditure on labor) in fact behaves very much like capital expenditure, incurred when the course is designed but expected to retain some value over the expected life of the course. While annualisation of traditional capital costs is commonplace, the annualisation of course development costs is less so. The failure to annualise course development costs is problematic given that the length of life over which courses last is a major factor in the overall efficiency of technology-based education.

At the macro-level the costs of any system are driven by a combination of the following factors, all of which are susceptible to management control:

- Course populations

- The number of courses offered

- The lengths of course lifetimes

- The media and technologies chosen

- The extent to which cost-inducing actions, for example, the use of copyrighted materials, are avoided

- The extent to which costs are placed on students, either as tuition, or by moving the system boundaries so that activities the institution might once have paid for are now paid for by students (e.g. access to tutorial and library services)

- The extent to which the institution employs people on contracts for service (i.e. salaried posts) to develop courses and teach students, rather than on contracts of service (i.e. hired as casual labor, to be paid by the manuscript/script/tutorial hour/test marked, etc.)

- The extent to which the institution adopts working practices that reduce the costs of labor by, for example, designing courses to be wrapped-around existing textbooks rather than developing new materials, and using author-editor models of course design, rather than big course team models

- The use of technology to increase the student load per academic or administrator

- Increases in the teaching load of academic staff at the expense of other functions - for example, research and public service, and ...

- 'Labor for labor' substitution - the replacement of expensive academic labor by student and adjunct labor, in order to reduce staff costs.

An important element in costing is to understand the system being costed so that cost elements are not missed. Far too many analysts restrict their analysis to their own budget. Of course, understanding one's own budget and controlling it is important. The answers one obtains to questions such as 'How much will this cost me?' and 'Will doing it this way cost more or less than doing it that way?' will help one decide whether, from a purely parochial interest, one should or should not proceed with a given course of action. However, the wider one's span of interest, the more one will want to look at the macro-picture. Individual teachers may be content to find out whether teaching online, for example, takes them more or less time than teaching face-to-face, but departmental heads will want to know whether they can teach more courses and/or more students per course, and what the effect will 
be on their expenditure and their income. Institutional heads will be concerned with all the above questions, but will also want to know what the impact is on administrative costs, while institutional heads and national educational planners may want to know whether teaching online is cheaper or more expensive than teaching face-to-face or by some other distance teaching methodology. Students will want to know whether taking a course online adds to their costs, or saves them money and/or time - and actually academics, course leaders, and institutional leaders should care deeply about student costs, since student decisions on whether or not to study with a particular institution will be driven in part by cost considerations. These considerations will go beyond the cost of tuition to cover the costs of engaging with the course ('Do I need a computer to study this course? What travel costs might I incur? How much will the materials I need cost me? Will I spend significant amounts of money online? What are there opportunity costs if I take this course?' etc.). This argues for a whole systems approach to the costing of projects that moves beyond the immediate concerns of individual course and departmental budgets to take account of the cost implications of the system as a whole on overhead functions and the customer.

The use of learning materials has already resulted in a sharp temporal differentiation between the design and delivery phases of the activity of teaching, with the design and production of complex multi-media courses beginning many months before they are taught, thus separating these activities in time (and often across budget years). Once created, the materials can be packaged in various ways and used, often for a number of years, on a range of different courses. They can also be used by very large numbers of students. All this makes it less likely that a single member of faculty will control the whole teaching-learning process from materials design through to delivery. On large population courses the chances are that not only will most of the actual interaction and assessment of students have to be farmed out to auxiliary teachers, but much of the administration of the teaching-learningassessment process will also be handed to professionals whose task it will be to seek economies of scale and process. Division of labor between those who design the materials, those who teach the courses, and those who administer and support student progress, follows. Indeed, the capital nature of the costs expended on course development, the division of labor that occurs in many systems, and the fact that materials once developed may be repackaged for use on a number of courses, argue for a clear distinction to be made between materials development and course delivery.

To date issues around the division of labor have been seen most clearly in distance education - most notably in large-scale 'first generation' correspondence systems, and in 'second generation' educational broadcasting and 'third generation' multi-media systems. This 'Fordist' tendency has been greatly criticized by those who see it as a reflection of the increasing degradation of academic work. It has been suggested that just as cottage-industry correspondence systems can be run by faculty who retain control over the whole teaching-learning process, so the development of online education allows faculty to teach at a distance without losing control of their course - and indeed this is true in some cases. However, a division of labor is likely to occur because in the long run any system that limits control of design and delivery to a single person limits both the range and sophistication of the materials that can be developed, and the number of students that can be supported, and is thus inherently cost-inefficient given the much greater economies of scale and process achievable in systems designed around the division of labor.

In addition, a range of more immediately personal issues arises for faculty involved in the development of materials. For example, will such an academic have to continue to teach traditional students in class at the same time as he or she develops the internet course? Will he/she be given time off to compensate them for the time spent developing the course, and if so who will help teach the traditional course? Will he/she be given no immediate help in the development of the course, but then be allowed - as happens in the French system - to substitute resource-based learning for personal teaching in the delivery phase, thus freeing up time that can then be spent on other more personal objectives (such as research and public service)? 
To these issues must be added issues around the actual teaching of online courses, including such issues as the evolution of new academic roles such as e-moderating [15], and the extent to which teaching online requires more or less time of academics.

So far we have focused on the use of the network for academic purposes - in essence as the location through which ethereal (i.e. non-physical) course materials can be accessed, and as the site through which electronic dialogue and discourse takes place. But a fully developed e-education system would use the network and website as the location for the administration of the learners' progress through the institution - that is, as the site through which students would electronically enrol, pay for their courses, change their records, and seek general counselling and advise. The development and maintenance of a web site to support academic and administrative functions must therefore be seen as an integral part of the provision of an e-education system, and hence of part of the costs of the system.

Those working within the teaching institution will of course be able to access the web site easily through the institution's own network - but remote tutors and students also need access to the web site. This generally means providing their own computing equipment and connections to the web though occasionally an institution may help by setting up tele-learning centers where students (and tutors) can make use of institutional equipment to access the site. Either way, the costs of access/reception are an integral part of the system as a whole, and need to be taken into account, if not for budgeting purposes, then at least for purposes of cost analysis.

On top of these elements are the costs of managing an e-education system. In virtual education institutions these overhead costs will be obvious, but in dual mode systems there is the possibility that these costs can be set aside, at least for a while, in order to give the e-education system a 'free' ride. Such free rides will not survive expansion, nor can they be ignored in cases where comparative costings between online and other systems are being attempted.

Thus the institutional costs of a fully developed e-education systems would include:

1. Developing e-materials

2. Teaching (and assessing) students online

3. Accessing the web site

4. Administering students online

5. Providing the infrastructure and support within which e-education can operate

6. Planning and managing e-education at the macro-level.

However, one is likely to find that the range of costs is very great. This arises in part because there are very different ideas as to what online learning actually is - varying from those who see it in terms of access to materials and to assessment schemes that favor multiple choice formats, to those who stress the communicative and constructivist nature of the dialogue that can occur between teacher and students, and among students. These different expectations of online learning are reflected in the costs of systems, making it hard to come to any concrete conclusions about their costs.

\section{COSTING ONLINE LEARNING}

In the light of the development of networked learning, a new generation of academics, interested in the impact of online learning on the costs of education, has begun to evolve a methodology by which to approach the task of costing such systems $[16,17,18,19,20]$. None of these studies provides a wholly comprehensive approach to the costs of networked learning. Such an approach would require an analysis that looked at the costs of a system: 
(a) by expenditure category (using the traditional distinctions between human resource or staff costs, premises and accommodation costs, equipment and furniture costs, and the costs of stocks, supplies, consumables and expenses), and

(b) by contributor (e.g. the institution's own budget, partner institutions' inputs, direct government inputs, aid agency inputs, staff inputs, and student inputs), while

(c) distinguishing between capital and revenue costs, with the former, including the investment in course materials, annualized over their expected life, and

(d) where this seems sensible to the analyst, using an appropriate systems framework for the analysis of costs.

If this provides a framework for the analysis of the costs of online learning, the next issue must be, exactly what kinds of costs are being identified, and how should they be treated? The first thing to say is that all the relevant costs should be identified. Secondly, costs should not be netted off from income since this hides the full costs involved. In fact, examination of the work done to date shows that the different analysts:

- Lack agreement on the costs that should be taken into account. This is particularly the case with regards to overhead costs (i.e. the costs analysed here within the regulatory and logistics subsystems) that are, in general, ignored.

- Employ very different labels or terms to describe what they are costing. This reflects jurisdictional and linguistic differences in terminology, local institutional practice, and personal preferences.

- Aggregate or disaggragate costs in different ways.

- Employ a variety of frameworks to give coherence to their work.

Appendices 1-3 look at the costs of online learning, using a functional approach as the primary thrust of the analysis to distinguish between the costs of online materials development (Appendix 1), eeducation delivery costs including teaching, assessment, and web access (Appendix 2), and overhead costs (Appendix 3). Within each of the tables that make up these appendices, column 1 of the table provides a brief description of the kind of expenditure involved, and this is then categorized (column 2 ) by expenditure type, viz. human resource (staff), buildings and accommodation, equipment and furniture, stocks, supplies, consumables and expenses. Finally, in column 3, there is a series of notes on the treatment of these costs.

While I have tried to be inclusive in my approach, I am conscious that there may be areas of cost that have not been identified either in sufficient detail, or at all. The items of expenditure identified should be regarded as illustrative rather than definitive. Analysts can, of course, adopt a different schema if they feel that this will be helpful.

However, the attempt to be inclusive does raise important issues about the scope of any costing project - that is, just how wide a range of costs should be included? Within an institution, this revolves largely around issues to do with the treatment of overhead costs, but there are wider ramifications - notably, the contributions made by other stakeholders including students and staff (particularly pertinent if time and expenses are not fully reimbursed). Any study that seeks to compare the costs of one system with another (say, the costs of networked learning with traditional teaching, whether within a single institution or across institutions) should take a full-cost approach. Where this is not done, the comparison risks being misleading.

\section{THE COSTS OF ONLINE LEARNING}

What do we know about the costs of networked learning? The major costs of e-education can be usefully considered under the three heads identified above - viz. the costs of developing web-based materials, the costs of e-education delivery, and the overhead costs of embarking on e-education. I shall take these in order. 


\section{A. Costs of developing online learning materials}

Most of the technologies involved in Web-based courses have been around for a long time. They include the preparation of text, audio, video, computer-based tutoring, intelligent tutoring, exploratory learning, simulations, etc. What is distinctive is that these materials are now being put on a web site that can then be accessed by students. For many years distance educators have known that not only do media and technologies have their own cost structures, but also that some media are more expensive than others. Bates's analysis of the costs of various media concluded that print, audio-cassettes, and pre-recorded Instructional Television are the only media that are relatively low cost for courses with populations of from under 250 students a year to over 1000 student a year. In addition, radio is also likely to be low cost on courses with populations of 1000 or more students [21 (p. 5)]. Hülsmann, on the basis of his study of the costs of 11 courses offered by 9 different European distance teaching organisations, argues that at $£ 350$ per student learning hour print is the cheapest medium to develop. Putting text up on the internet costs at least twice that, and possibly more. After that costs escalate through audio (£1,700), CD-ROM (£13,000), video (£35,000) and TV (£121,000) [22 (p. 17)].

These figures are based on averages across eleven courses in nine institutions, and hence need to be treated with care, given the wide variations in costs encountered in practice. However, the broad differences in media costs are carried through into the development of internet-based courses. Arizona Learning Systems found a wide variation in the costs of developing a course, of from US\$6000 to $\$ 1,000,000$ for a three unit internet course, depending on the approach used. Much of this is the cost of academic and technical labor. The cheapest approach involved the presentation of simple course outlines and assignments; the most expensive, at $\$ 1,000,000$, involved virtual reality [23 (pp. 13-14)] (see Table 1).

Table 1: Cost of developing a three-unit internet course (US\$)

(Arizona Learning Systems, 1998)

\begin{tabular}{|l|r|}
\hline Course outlines and assignments & 6,000 \\
\hline Text & 12,000 \\
\hline Text with reference material & 18,000 \\
\hline Text with reference material and images & 37,500 \\
\hline Audio and video & 120,000 \\
\hline Simulations & 250,000 \\
\hline Virtual Reality & $1,000,000$ \\
\hline
\end{tabular}

The high costs of developing internet courses are confirmed by Saba, who suggests that commercial software companies developing courses for online instruction or publishers are spending at least $\$ 500,000$ to fully develop a multimedia course [24].

There is some evidence that the lower levels of cost are more likely to be found on synchronous online courses, with asynchronous courses costing more. Certainly Whalen and Wright found significant differences between synchronous and asynchronous course development costs. The former required much less development time because they involved fewer media [25 (p. 32)].

A high proportion of the costs of developing materials is labor costs. All the research shows that it takes more academic time to develop media that will occupy a student for one hour, than it takes to develop a one hour lecture - although how much more time is difficult to quantify. Sparkes reckoned that it took from 2 to 10 hours to prepare a lecture, from 1 to 10 hours to prepare a small group session, and from 3 to 10 hours to prepare a video-tape lecture; however, it took at least 50 to 100 academic hours to prepare a teaching text, 100 hours to prepare a television broadcast, 200 hours to develop computer-aided learning, and 300 hours to develop interactive materials - to which in all cases one needed to add the time of technical support staff [26 (p.219)]. Boettcher suggests that it takes an average of about 18 hours faculty time to create an hour of instruction online [27]. Academic 
development costs can be reduced or at least kept in check by adopting cheaper approaches to course development - for example, author-editor models based on an editor working with consultant authors, instead of hiring permanent staff.

One of the problems with many of the studies now available is that they report the broad results, not the detail. It is therefore difficult to know what has been included and what excluded, and so whether the costings undertaken are comprehensive. Experience suggests, however, that all figures need to be treated with care. What does seem clear is that the costs of developing a course are being pushed up and significantly so whenever media are used in a sophisticated way. If so, and if cost efficiency is an important consideration, then savings may need to be looked for in delivery.

\section{B. The costs of e-delivery}

Although the development costs of even relatively simple online materials may be higher than paperbased print, it seems fairly clear that there are considerable institutional savings on delivery costs. The Library of Virginia has digitized the state's colonial records. This has drastically reduced the costs of fulfilling requests from readers. The costs to the library of providing a single copy of a four page report in digital format is just 90 US cents, compared with $\$ 19$ to supply a surface-mail customer, and $\$ 12$ to supply an on-site user [28]. Applied to course materials, online delivery to order could cut inventory, packing, and postage costs enormously. Online library services like those offered or under development by XanEdu and Questia are likely to be invaluable - provided the subscription rates that users are to be charged are not unreasonably high. However, students used to their course materials dropping through their letterboxes are likely to see their study costs rise as they access and perhaps pay for materials online, and print them off themselves.

What about the costs of computer-mediated communications and assessment? Here we get into the costs of labor and the problems of student load. Bates has suggested that in comparison with face-toface teaching, CMC will lower the costs of tuition because a good deal of the students' time is spent studying the material, and so the teacher needs to spend less time per student overall in class [28 (pp. 126-7)]. Other analysts argue that students will also spend a great deal more time learning from their peers, and that this too will reduce the demands they make of their tutors. Certainly DiBiase, teaching for Penn State University's World Campus, found that he and his Teaching Assistant were spending less time supporting students on an online course (1.6 hours per student against 2.6 hours on a regular course) [30 (pp. 15-16].

However, the general consensus seems to be that online tutoring adds to traditional faculty workload [23 (p. 20); 30] given the enormous volume of messaging [32] arising from increased interaction with students [33 (p. 37)], with each message requiring more time to compose than is the case in verbal interactions [34 (p. 223)]. For faculty, teaching online opens up the possibility that they are always in session - which translates into 'taking more time' [35]. Moonen thinks that the increased load would be of the order of 5 to 10 hours a week for a class of 60 to 120 students [32]. Jewett thinks tutors could well spend twice as much time tutoring online as they do face-to-face [33 (p. 41)]. This raises the question of how many students an online instructor can handle. In classroom courses in the USA it looks as if people think they can handle from 25 to 30 students, working perhaps 10 to 12 hours a week. Boettcher suggests that experience indicates that a member of faculty can handle more students on a web course - in the range 25 to 65 , but that this will require more time - so that although there are courses with $50-60$ students on them, there are many courses where student numbers are deliberately kept down, somewhere in the range of from 12 to 20 students [36].

One way of coping with an academic's increased workload is to hire more staff but this, of course, costs more. However, the impact on labor costs can be reduced through 'labor-for-labor' substitution - that is, the substitution of cheap labor for expensive faculty labor. This cheap labor might be students [31], teaching assistants, or clerks covering help desks [23 (p. 24)]. These options are much discussed in the US literature. However, hiring cheaper labor is not possible in small classes run by just one academic; it only works in large classes [31]. Also, labor-for-labor substitution has its critics. 
Traditionally PhD students have helped teach courses but student labor is not the cheapest labor on offer. Adjunct staff hired by the class is even less expensive - so much so that there is concern that their employment could damage graduate programmes by reducing the employment opportunities for $\mathrm{PhD}$ students [37].

Up to now I have been talking about the impact of CMC on the costs of traditional institutions. What about its impact on the costs of distance education delivery? Firstly, there is evidence that distance tutors spend more time moderating and tutoring e-courses. Tolley, drawing on her experience as a UK Open University tutor, found that she spent more than twice as many hours tutoring the online version of What is Europe? as she did the 'traditional' version - 120 hours against 48 [38 (p. 263)]. She was not paid for the additional work, which also had a dramatic effect on her 'phone bill. Annand, from his perspective at Athabasca University, suggests that it is these costs that may in the end constrain the extent to which large-scale distance teaching universities can adopt online technologies [39 (p. 20)]. Some institutions are trying to find ways of containing demands on tutor time by controlling student expectations and limiting the time for engagement on a particular topic; others, like the eUniversity, might subcontract tutoring to commercial ventures like Tutor.com, which will charge students for the service [40 (paragraphs 79-80)].

Secondly, there are the costs of reception. Cost analysis tends to be bounded by the institutional budget. The costs students incur in acquiring and operating equipment is not generally taken into account - yet from the would-be student's point of view, these costs can have a major impact on affordability, and hence on access. In the USA the distribution of computers is highly graduated by income, race/ethnicity, and educational attainment [41]. In the Third World, the situation is much worse. If owning the equipment is a necessary condition for participation, then expect to see more disadvantaged people being excluded on cost grounds.

Local centers may, of course, mitigate student costs by providing access to machines, but they cost a fair amount in rent, equipment, furniture and staffing to set up - and generally accommodate very few students at any one time. This is not a solution to mass access - which is why the African Virtual University is such a limited project. Internet cafés cost money to use and are not necessarily ideal environments for study. In any case, in a country like Uganda, anything that uses a telephone line is extremely expensive.

The assumption behind many of the cases put forward to support the development of e-teaching is that the technology will substitute for the labor costs of teaching. Students will, it is assumed, spend a lot more of their time studying independently from the materials, and much less time in formal classes. One potential advantage is that this will make more faculty time available for students to discuss with their teachers what they have learnt independently [42] - but if so, any savings in faculty time disappear and are likely to be at most modest [43]. If there are no savings on faculty time, then the argument begins to focus on balancing the additional technology costs against sometimes more tenuous accommodation savings - which is not to say that some projects such as the Florida Gulf Coast University do not hope to make substantial savings on building costs [43]. In any case, as Massy and Zemsky [42] comment, actually achieving capital for labor substitutions may prove difficult for many colleges.

One other factor is the extent to which faculty are properly reimbursed for the costs they incur when teaching online. Schifter [35\} reports the very wide range of practice that occurs. Her analysis suggests that many distance teachers do not have their costs reimbursed.

Generally speaking, there are powerful incentives to bring the costs of teaching down. In a situation where the technology, far from reducing contact hours, may be actually increasing faculty hours spent in contact with students, there are powerful pressures to reduce faculty labor costs by substituting cheaper for more expensive labor. This does not always replace experienced by inexperienced staff; some systems go out of their way to hire recently retired faculty who are looking to supplement their incomes. Nevertheless, the fact remains that the pressure is on to reduce costs. Mass education 
distance teaching universities such as Britain's Open University, with some courses having over 10,000 students enrolled at the same time, have had to employ models based on a division of labor between those who develop the course materials, those who teach/tutor, and those who mark examination scripts. Not surprisingly the Open University employs its tutors and script markers on contracts of service. Institutions that restrict the number of students taking distance courses do not have the same problem. Certainly with the exception of a few institutions such as the non-traditional University of Phoenix, practice in America has generally not led to any systematic restructuring of academic labor force [44]. Nevertheless, a general increase in the use of adjunct and part-time faculty has been noted [45], while the pressures to massify and reduce costs must give managers an incentive to hire casual labor.

Another factor at play here is the extent to which costs that used to be met by the teaching institution - or at least were wrapped up in the tuition fees charged - are now being pushed on to students quite overtly.

\section{The costs of e-administration}

We know very little about the costs of e-administration, but on the whole this may be the area where savings are most likely to occur. Service costs in a range of industries are being brought down as institutions invert traditional processes, such as student services, to focus more on Web-based, selfservice models [46 (p. 17)]. A paper-based order costs about $\$ 65$ to fulfil - but it only costs around $\$ 5$ to fulfil an online order [47 (p. 23)]. A paper-based invoice may cost US $\$ 0.90$ to produce and distribute; online services can reduce this to something like $\$ 0.40$ - $\$ 0.60$ [48], and speed the whole process up. Perhaps $75 \%$ to $90 \%$ of transactions currently done manually and on paper should be done electronically [46 (p. 17)]. This trend will impact on all educational institutions.

E-commerce practices are also invading education to provide income streams. Many US campuses are now allowing advertising on their web sites - with the income from advertising offsetting the cost of the site [46 (p. 15)]. Some universities - such as Georgetown University - have auctioned spare course capacity on the Internet, with bidders hoping, of course, to get a place on an expensive course at a discount [46 (p. 15)]. We can expect eduCommerce to proliferate [46 (p. 15)]. Certainly the eUniversity Business Model assumes that this kind of activity will occur [40 (paragraphs 194-5)].

Nevertheless, entering the e-commerce market has its costs. A Gartner Group report suggests that ecommerce web sites are harder than expected to build, with costs of US\$1 million on average - and that this cost is likely to increase by $25 \%$ per annum over the next 2 years. Of this cost, $79 \%$ is laborrelated, $11 \%$ hardware, and 10\% software [49]. Few cost studies of online learning appear to cost the development of the web site at anything like this level of expenditure. This must be a cost in the development of a virtual university. In mixed mode institutions, only part of these costs would now generally relate to the development of an online learning capability. However, the costs of a web site supporting a sophisticated online administrative function are likely to be high.

In general none of the studies undertaken to date adequately factor in the costs of overheads. Although, the costs of putting in equipment directly associated with the projects (e.g., servers) are usually taken into account, as are the costs of software licenses, college operating budgets do not usually reflect the full costs of maintaining networked services [50]. This is something that the US COSTS project is tackling [50,51]. The annualisation of equipment also causes problems. Most of the cost studies annualise equipment over five years [17, 23], but in the US in 1998/99 the typical replacement cycle for computers was 3 to 5 years; for central servers 3 to 4 years; and for network electronics, 5 to 6 years [51]. This may seem insignificant - but it impacts on costs significantly, and even more so when the opportunity cost of capital is taken into account. Replacement costs, which tend to rise, are often under-estimated: Ritschard and Spencer [52] argue that the theoretical replacement cost is the average cost per machine times the number of machines to be replaced. They suggest that annual provision for replacement of computers needs to run at $61 \%$ of the theoretical replacement cost. Provision for upgrades of equipment that will not be replaced like-for-like requires 
an additional $8 \%$ of the theoretical budget. Another $6 \%$ needs to be set aside for unplanned replacements and unforeseen contingencies; a further $20 \%$ budgeted for new staff positions; and another $5 \%$ for 'out-of-cycle' changes and upgrades.

Finally, higher-level management costs, including planning and evaluation, are rarely taken into account. Overhead management time is often hard to identify. Much depends on the context -the time spent agreeing that a group of enthusiasts can develop a project will be very different to that required to change an institution's direction. Indeed, developing an IT strategy is likely to be expensive [29, 53].

These omissions are not always obvious from the cost studies. As this section of the paper makes clear, there are both significant costs involved, and the potential for significant savings in administration. The fact that overhead costs and savings are not built into comparative studies of the costs of online, traditional, and other forms of distance education, must mean that any conclusions drawn from such comparative studies have to be treated with care.

\section{COMPARING THE COSTS OF E-EDUCATION WITH OTHER FORMS OF EDUCATION}

Having looked at the costs involved in online education, let us look at how the costs of e-education courses compare firstly with those of class-based education, and secondly with other forms of distance education.

\section{A. Comparing e-education costs with the costs of face-to-face education}

Whether one system is more or less expensive than another will depend upon a range of factors such as those I discussed earlier. One approach is to substitute CMC for face-to-face tuition - leaving everything else unchanged. A study conducted at the University of Illinois found that unit costs came down on all nine courses in which asynchronous learning networks were substituted for face-to-face instruction [31]. Bates also thinks that online university courses using just $\mathrm{CMC}$, and involving no real e-materials development, will be cheaper than face-to-face courses [29 (pp. 126-7)]. However, most online courses involve some materials, so that cost-efficiency depends on the number of students enrolled. Bates suggests that a standard Web-based course, with a mix of pre-prepared Web materials, online discussion forums, and print in the form of required texts, is increasingly more cost-effective than face-to-face teaching as numbers per class increase beyond 40 per year over a four-year period. Under 20 students, it is not economically worth doing. Between 20 and 40 students per year per course, any cost differences are likely to be less significant than differences in benefits [29 (pp. 1289)].

If we widen the argument to take into account training costs that fall on employers, then we find that there are stronger reasons to believe in savings. There is general agreement that online training courses are less expensive that face-to-face ones provided the development costs are spread across sufficient numbers of students (possibly over several years), and provided that one takes into account both savings on travel and accommodation costs, and the fact that less of an employee's productive time is lost (employees now train in their own time rather than in the firm's time) [54 (pp. 142-3); 55 (pp. 12-14); 17 (p. 40)].

However, things do not look so good once purpose-built materials are added in: Bates says that if as well as having $\mathrm{CMC}$, one also develops purpose-built materials, then the unit costs will be more expensive than face-to-face tuition [29 (p.128)]. Arizona Learning Systems found that the cost per course enrolment of an 'average' Internet course (US\$571) is higher than that of traditional classroom instruction (\$474), though labor-for-labor substitution might bring this down to $\$ 447$ [23 (p. 24)]. However, much depends on the nature of the materials and their associated development costs which, as we saw, they estimated to vary from US\$6000 to $\$ 1,000,000$ for a three unit Internet course [23 (pp. 13-14)]. 


\section{B. Comparing e-education costs with the costs of other forms of distance education}

What about the cost comparison with other forms of distance education? We have very few studies go on. In an Australian study, Inglis found the online version of a course was less cost efficient at all levels of enrolment than a print-based distance education course [34 (p. 233)] (Table 2).

Table 2: Average cost per student of print and online versions of a course

Source: Inglis (1999: 231)

\begin{tabular}{|c|c|c|}
\hline & \multicolumn{2}{|c|}{$\begin{array}{c}\text { Average cost per student: } \\
\text { 1999 Aus\$ }\end{array}$} \\
\hline $\begin{array}{c}\text { Volume of } \\
\text { students }\end{array}$ & Print version & Online \\
\hline 50 & 169.84 & 217.71 \\
\hline 100 & 125.38 & 171.63 \\
\hline 150 & 110.56 & 156.27 \\
\hline 200 & 103.15 & 148.59 \\
\hline
\end{tabular}

Elsewhere, Jung compared the costs of presenting standard three credit courses at the Korea National Open University. The course involving textbooks, CD-ROM and electronic tuition was more expensive than the courses using textbooks, radio and face-to-face tuition, or those using textbooks, television and face-to-face tuition. However, dropout was only $10 \%$ on the e-course, compared with $60 \%$ on the other two types [56 (pp. 228-9)] (Table 3).

Table 3: Costs of distance education at the Korea National Open University

Source: Jung (2000: 229)

\begin{tabular}{|l|l|l|c|}
\hline & \multicolumn{1}{|c|}{ TV-based course } & Radio-based course & \multicolumn{1}{c|}{ Web-based course } \\
\hline Rating & 16 week, 3 credit & 16 week, 3 credit & 16 week, 3 credit \\
\hline Media & $\begin{array}{l}\text { Textbook, TV } \\
\text { programmes and } \\
\text { face-to-face tuition }\end{array}$ & $\begin{array}{l}\text { Textbook, radio } \\
\text { programmes and } \\
\text { face-to-face tuition }\end{array}$ & $\begin{array}{l}\text { Textbook, video- and } \\
\text { audio-clips, electronic } \\
\text { tuition }\end{array}$ \\
\hline Number of students & 1000 & 1000 & 30 \\
\hline Cost to produce and deliver US\$ & 80000 & 35000 & 13000 \\
\hline Cost per student US\$ & 80 & 35 & 434 \\
\hline Dropout rate (\%) & 60 & 60 & 10 \\
\hline Cost per completed student US\$ & 200 & 87.5 & 482 \\
\hline
\end{tabular}

Overall, then, these studies suggest that e-education is pushing the costs of distance education up. Some of these additional costs are being passed onto the students, but not all of them. And while no doubt the costs of the technology will come down, the fact remains that those who are not able to afford e-education are being written out of the game. This is true within developed countries, at least in respect of some sectors of the population, but much more widely the case in developing countries [57 (p. 150)].

\section{WHAT OUTPUT IS BEING COSTED?}

The output measures used in cost studies vary from study to study. Some studies are based on the cost per student and/or the cost per graduate, but while this may be a suitable measure of output on which to make cost comparisons between educational systems and institutions, for most purposes a better measure is the cost per student per course. Courses are not, however, standard entities - and hence many studies seek to qualify this measure by defining the kind of course that is being costed in terms of a 'standard' course measured in credit points or credit hours. Unfortunately this also has its problems because internationally the credit weighting of a course may relate to a different things: 
(a) the total expected number of hours that the average student will spend studying the course. This measure applies in the UK, for example, where there is an assumption that a standard three year Bachelor's degree will require 120 credit points of study per year, with each credit point being equivalent to something like 10 hours study.

(b) the total timetabled weekly contact hours - which is the system found in the USA - and which of course does not reflect the actual hours study put in by students.

Distance education courses by definition do away with or at least sharply reduce the amount of contact between teachers and students, replacing this with independent study. The latter may be based upon reading, listening to, watching, or otherwise engaging with learning materials; doing assignments and tests; or general reflection. This means that the actual time spent studying the materials may have little relation with the total study time theoretically assigned to the course. For example, Hülsmann [22 (p. 42)] found that the faculty who developed a British Open University course on mathematical modelling estimated that the course would require some 448 hours study over the year - but that the actual time spent studying the various mediated elements of the course (text, CD-ROM, video) was estimated to be 336 hours - so that the course study hours were 1.5 times the media study hours. On the other hand, a course for teachers and social workers offered by NKS Norway required 700 hours study, but only 106 hours of this study arose from the studying the print and video materials provided. Here course hours were 6.8 times the media study hours. These differences leads Hülsmann to suggest that the most appropriate approach to costing media is separately to divide the cost of developing and delivering a given medium by the number of student study hours the medium gives rise to. Thus, for example, a 50 page text that cost $£ 17,500$ to develop and that takes an estimated (and average) 5 hours to study has a development cost per student study hour of $£ 350$, while a one-hour audiotape that cost $£ 1700$ to develop, and takes one hour to study, has a cost per student study hour of $£ 1700$ [22 (p. 17)]. Although there is an element of subjectivity in estimating how long an (average) student will spend studying a particular element of course material, this does give an easy guide to the relative costs of different media. In practice, however, there is a range of factors that impinge on the costs of developing and delivering media - not least questions related to the quality of the materials and the organisational structure and labor market conditions that underpin its development/delivery - and these differences are almost certainly behind the range of costs per student study hour that Hülsmann found in practice across the 11 courses that he studied [22 (p. 145)]. Having said that, the approach enabled him to show the rough order of costs involved, and to establish beyond reasonable doubt that Internet-based text is more expensive than printed text (by a factor of 2), with the cheaper media being print and audio. Certainly Hülsmann's approach to the measurement of outputs has a great deal to commend it.

\section{CONCLUSIONS}

This paper has sought to do two things: firstly, to review the current approaches to costing e-education and to suggest how this might be best approached, having regard to the issues that have been identified, and in the light of the methodological considerations identified, to look at some of the current range of cost comparisons available. Hopefully it will stimulate others to undertake more cost studies - if only to ensure that we know the costs of the direction upon which we now seem to be embarked.

\section{REFERENCES}

1. Coombs, P. H. The world educational crisis: A systems analysis, Oxford, Oxford University Press, 1968.

2. Vaizey, J. The costs of education, London, Faber, 1958.

3. Schultz, T. Investment in human capital, American Economic Review 51, 1-17, 1961.

4. Rumble, G., Cost analysis of distance learning, Performance Improvement Quarterly, 12 (2), 122-37, 1999.

5. Jamison, D. T., Klees, S. J. and Wells, S. J. The costs of educational media. Guidelines for planning and evaluation, Beverly Hills, Sage Publications, 1978. Published earlier as Jamison, D. T., Klees, S. J. and Wells, S. J., Cost analysis for educational planning and evaluation: 
Methodology and application to instructional television, Washington, D. C., U.S. Agency for International Development, 1976.

6. Eicher, J.-C. Some thoughts on the economic analysis of new educational media. In UNESCO, The economics of new educational media. Vol. 2: Cost and effectiveness, Paris, The UNESCO Press, 1980.

7. Eicher, J.-C., Hawkridge, D., McAnany, E., Mariet, F. \& Orivel, F. The economics of new educational media. Volume 3: Cost and effectiveness overview and synthesis, Paris, The UNESCO Press, 1982.

8. Orivel, F. Analysing costs in distance education systems: a methodological approach, Dijon, Université de Bourgogne, IREDU, mimeo, 1987. Reprinted in Oliveira, J. B. and Rumble, G. (eds.), Educación a Distancia en América Latina: Análisis de costo-efectividad, Washington, D.C., World Bank, 1992.

9. Fielden, J. and Pearson, P. K. Costing educational practice, London, Council for Educational Technology, 1978.

10. Crabb, G. (ed.) Costing open and flexible learning. A practical guide, London, National Council for Educational Technology, 1990.

11. Rumble G. Costing distance education, London, Commonwealth Secretariat, 1986.

12. Rumble, G. The costs and costing of distance/open education. In Jenkins, J, (ed.), Commonwealth co-operation in open learning: background papers, London, Commonwealth Secretariat, 1988.

13. Rumble, G. Activity costing in mixed-mode institutions: a report based on a study of Deakin University, Geelong, Victoria, Deakin University, Distance Education Unit, 1986.

14. Deakin University, Further investigations into activity costing in a mixed mode institution, Department of Employment, Education and Training, Commonwealth of Australia, 1989.

15. Salmon, E. E-moderating: The key to teaching and learning online, London, Kogan Page, 2000.

16. Boucher, A. Information Technology-based Teaching and Learning in Higher Education: a view of the economic issues, Journal of Information Technology for Teacher Education, 7 (1), 87-111, 1998.

17. Whalen, T. and Wright, D. Cost-benefit analysis of web-based tele-learning: Case Study of the Bell Online Institute Pilot Project, University of Ottawa, Faculty of Administration, July 1998.

18. Bacsich, P., Ash, C., Boniwell, K., Kaplan, L. with Mardell, J. and Caven-Atack, A. The cost of networked learning, Sheffield, Sheffield Hallam University, Telematics in Education Research Group, 1999.

19. Webb, G. and Cilesio, C. An investigation into the costs and benefits of Internet-based delivery: Paper delivered to the Open Learning Conference, Brisbane, Australia, December 1998. Available at http://vc.tafensw.edu.au/staff/gwebb/ol98/paper.htm

20. Webb, G. and Cilesio, C. The costs and benefits of online delivery. Paper presented to the ODLAA Conference, Geelong, Victoria, Australia, August 1999. Available at http://vc/tafensw.edu.au/site/it/library/99wecio3/99weci03.htm

21. Bates, A. W. Technology, Open Learning and Distance Education, London: Routledge, 1995.

22. Hülsmann, T. The Costs of Open Learning: A Handbook, Oldenburg, Bibliothecks-und Informationssystem der Carl von Ossietsky Universität Oldenburg, 2000.

23. Arizona Learning Systems, Preliminary cost methodology for distance learning, Arizona Learning Systems and the State Board of Directors for Community Colleges of Arizona, 1998.

24. Saba, F. Software systems in distance teaching and learning, Distance Education Report, 1999. Available at http://magnapubs.com/Newsletters/Der/software3.7.htm

25. Whalen, T. and Wright, D. Methodology for Cost-benefit analysis of web-based tele-learning: Case Study of the Bell Online Institute, American Journal of Distance Education 13 (1), 24-44, 1999.

26. Sparkes, J. 'Pedagogic differences in course design'. In Bates, A. (ed.) The role of technology in distance education, London, Croom Helm, 1984.

27. Boettcher, J. V. How much time does it cost to develop a distance learning course? It all depends ..., 1999. Available at http://www.cren.net/ jboettch/dlmay.htm 
28. Roderick, E. More than just pretty pictures: A cost/benefit analysis of digital library holdings. A paper presented to the CAUSE98 Conference, Seattle, December 1998. Available at http://www.educause/edu/copyright.html

29. Bates, A. W. Managing technological change. Strategies for college and university leaders, San Francisco, Jossey-Bass Publishers, 2000.

30. DiBiase, D. 'Is distance teaching more work or less?', American Journal of Distance Education 14 (3), 6-20, 2000.

31. Arvan, L., Ory, J. C., Bullock, C. D., Burnaska, K. K., and Hanson, M. The SCALE Efficiency Projects, Journal of Asynchronous Learning Networks 2 (2), 1998. Available at http://www.aln.org/alnweb/journal/vol2_issue2/arvan2.htm

32. Moonen, J. 'The efficiency of telelearning', Journal of Asynchronous Networked Learning, 1 (2), 1997. Available at http://www.aln.org/alnweb/journal/issue2/moonen.htm

33. Jewitt, F. A Framework for the comparative analysis of the costs of classroom instruction vìs-avis distributed instruction. Study undertaken for the New Jersey Institute for Collegiate Teaching and Learning. California State University, March 1999.

34. Inglis, A. 'Is online delivery less costly than print and is it meaningful to ask?', Distance Education, 20 (2), 220-39, 1999.

35. Schifter, C. C. Compensation models in distance education, Journal of Distance Education Administration, 3 (1), 2000. Available at http://www.westga.edu/ distance/schifter31.html

36. Boettcher, J. V. How many students are just right in a web course? 1999. Available at http://www.cren.net/ jboettch/number.htm

37. Turoff, M. 'Costs for the development of a Virtual University', Journal of Asynchronous Learning Networks, 1 (1), March 1997. Available at http://aln.org/alnweb/journal/jaln_Vollissue1.htm

38. Tolley, S. How electronic conferencing affects the way we teach, Open Learning, 15 (3), 253 $65,2000$.

39. Annand, D. 'The problem of computer conferencing for distance-based universities', Open Learning, 14 (3), 47-52, 1999.

40. PricewaterhouseCoopers, Business model for the e-University, Main report, 2000. Available at http://www.hefce.ac.uk/pubs/HEFCE/2000/00 44.htm

41. Gladieux, L. E. and Swail, W. S. 'The Internet: New engine of inequality?' Paper presented to the EDUCAUSE'99 Conference, 1999. Available at http://www.educause.edu/ir/library/html

42. Massy, W. F. and Zemsky, R. Using Information Technology to enhance academic productivity, Wingspread Enhancing Academic Productivity Conference, June 1995. Available at http://www.educause.edu/nlii/keydocs/massy.html

43. Arvan, L. The economics of ALN: Some issues, Journal of Asynchronous Learning Networks, 1 (1), March 1997. Available at http://www.aln.org/alnweb/journal/issue1/arvan.htm

44. Berg, G. A. Early patterns of faculty compensation for developing and teaching distance learning courses, Journal of Asynchronous Learning Networks, 4 (1), 2000. Available at http://www.aln.org/alnweb/journal/Vol4 issue1/berg.htm

45. Finkelstein, M. J., Seal, R. K., and Schuster, J. H. The new academic generation: A profession in transformation, Baltimore, John Hopkins University, 1998.

46. Oblinger, D. 'Will e-business shape the future of open and distance learning?', Open Learning 16 (1), 9-24, 2001.

47. Naughton, J. 'Much more than a bubble', The Observer [London], 31 December 2000. PwC, Technology Forecast: 1999, Menlo Poark, CA, PricewaterhouseCoopers Technology Center, 1998.

48. Farmer, M. A. Study: E-commerce sites pricey to build, CNET News.com, 1999. Available at http://news.cnet.com/news/o-10007-202-343016.html

49. Leach, K. and Smallen, D. 'What do Information Technology support services really cost?', CAUSE/EFFECT 21 (2), 38-45, 1998. Available at http://www.educause.edu/ir/library/html

50. Leach, K. and Smallen, D. 'What do we really understand about the cost of IT support services?' Presentation to the EDUCAUSE 2000 Conference, 2000. Available at http://www.costproject.org/ 
51. Ritschard, M. R. and Spenser, E. L. Planning for technology replacement: Is it possible? Paper presented to the College and University Information Services Conference CUMREC'99, 1999. Available at http://www.educause.edu/ir/library/html

52. Daniel, J. S. Mega-universities and Knowledge Media. Technology Strategies for Higher Education, London, Kogan Page, 1996.

53. Ravet, S. and Layte, M. Technology-based Training. A Comprehensive Guide to Choosing, Implementing, Managing and Developing New Technologies in Training, London, Kogan Page, 1997.

54. Phelps, R. H., Wells, R. A., Ashworth Jr., R. L., \& Hahn, H. A. 'Effectiveness and costs of distance education using computer-mediated communication', The American Journal of Distance Education 5 (3), 7-19, 1991.

55. Inglis, A. 'Is online delivery less costly than print and is it meaningful to ask?', Distance Education 20 (2), 220-39, 1999.

56. Jung, I. 'Technology innovations and the development of distance education: Korean experience', Open Learning 15 (3), 217-32, 2000.

57. Perraton, H. Open and Distance Learning in the Developing World, London, Routledge, 2000.

58. Moran, L. Distance education, copyright and communication in the Information Society, Report prepared for UNESCO meeting of the Committee of Experts on Copyright in the Information Society, New Delhi, India, November 1996.

\section{Appendices}

\section{Appendix 1: Developing e-materials}

\begin{tabular}{lll}
\hline Expenditure descriptor & $\begin{array}{l}\text { Expenditure } \\
\text { category }\end{array}$ & Comments \\
\hline Materials & $\begin{array}{l}\text { General } \\
\text { comment }\end{array}$ & $\begin{array}{l}\text { Internet courses may involve a range of media ranging } \\
\text { from a brief course outline linked to existing textbooks; } \\
\text { texts (content) online; texts + reference materials; }\end{array}$ \\
& $\begin{array}{l}\text { images; audio; video; simulations; and virtual reality } \\
\text { [23, also 22]. Media choice has a considerable impact } \\
\text { on development and production costs. }\end{array}$
\end{tabular}

Materials are usually developed to last several years, so there is an argument for annualising their costs over the life of the course.

Most materials relate to the subject being studied. However, some are of a more administrative nature information on rules and regulations relating to the course, information on examination arrangements, etc. Such materials properly constitute a cost of a particular given course.

Yet other materials may be sent to all the students registered on a group of courses - in which case the cost of these materials would need to be apportioned across the courses (or course enrolments).

Not all materials need be supplied direct by the institution. In some cases students will be asked to buy commercially available textbooks, videos, software, etc. These costs are properly a cost of the course - but incurred by the student. Any full-costs study would need to recognise such costs. 
Cost of staff time spent on developing materials

- instructional design

- content development

- text authoring

- $\quad$ software development

- multimedia design and production

- course specific software development

- content integration and testing

- post-test modification costs

- $\quad$ training
Human The actual amount of time involved in developing Resources courseware varies significantly depending on media [26].

How jobs are packaged varies considerably. Many large-scale distance teaching institutions divide the labor between those who develop materials, those who teach, and those who mark examinations. Development roles may also be distinct, with divisions between, for example instructional design, content development, content editing, graphic design, etc.

Some systems use core staff on full-time salaries with benefits; others use consultants paid by output.

In dual mode systems, the preparation of online materials may be regarded as an extra duty, attracting additional payments/compensation (overload pay). Or staff may be relieved of other duties (release time) This may well represent an additional cost to the employer if this time has to be replaced. On this see [35].

\begin{tabular}{|c|c|c|}
\hline Staff equipment & Equipment & $\begin{array}{l}\text { Some systems may purchase computers and software to } \\
\text { enable staff to develop courses; others expect staff } \\
\text { (particularly consultants) to provide their own [35]. }\end{array}$ \\
\hline $\begin{array}{l}\text { Staff expenses arising during } \\
\text { development of materials }\end{array}$ & Expenses & $\begin{array}{l}\text { The extent to which development staff have their ISP } \\
\text { costs met varies [35]. }\end{array}$ \\
\hline Copyright clearance & Expenses & $\begin{array}{l}\text { Third party copyright can be a significant expense - so } \\
\text { much so that some systems may decide not to use any } \\
\text { third party material at all }[58] \text {. }\end{array}$ \\
\hline Materials production & & \\
\hline \begin{tabular}{ll}
\multicolumn{2}{l}{ Production costs } \\
$-\quad$ text production \\
$-\quad$ audio production \\
$-\quad$ video production \\
$-\quad$ graphics production \\
$-\quad$ software production
\end{tabular} & $\begin{array}{l}\text { Staff costs, } \\
\text { Stocks, } \\
\text { Supplies, } \\
\text { Consumables }\end{array}$ & $\begin{array}{l}\text { e.g. costs of producing a CD-ROM for delivery to each } \\
\text { student on a course }\end{array}$ \\
\hline
\end{tabular}

Staff costs As for original production costs. The degree of remake

Expenses may vary, but some revisions - for example, the development of new assignment and examination questions, may be a regular feature of course maintenance.

\begin{tabular}{lll}
\hline $\begin{array}{l}\text { Developmental testing of } \\
\text { course }\end{array}$ & $\begin{array}{l}\text { Staff costs } \\
\text { Expenses }\end{array}$ & $\begin{array}{l}\text { Payments to course testers; general running costs of } \\
\text { developmental testing }\end{array}$
\end{tabular}




\section{Appendix 2: E-delivery costs}

\begin{tabular}{|c|c|c|}
\hline Expenditure descriptor & $\begin{array}{l}\text { Expenditure } \\
\text { category }\end{array}$ & Comments \\
\hline $\begin{array}{l}\text { Materials delivery } \\
\text { Distribution of courseware } \\
\text { (e.g. CD-ROMs, user manual, } \\
\text { electronic materials, etc) to } \\
\text { students }\end{array}$ & Expense & $\begin{array}{l}\text { Postage, courier, etc costs arising from the distribution } \\
\text { of physical goods. Online delivery costs of 'ethereal' } \\
\text { goods. }\end{array}$ \\
\hline
\end{tabular}

\begin{tabular}{lll}
\hline $\begin{array}{l}\text { Materials reception expenses } \\
\text { Any expenses incurred by } \\
\text { those receiving the materials }\end{array}$ & Expense & $\begin{array}{l}\text { This might include incidental costs of reception, costs of } \\
\text { purchasing materials, etc. }\end{array}$ \\
\hline
\end{tabular}

Student/tutor equipment

Network/computers/printer

Equipment (capital)

Few institutions now provide students with computers and most analysts (e.g. [22]) assume that students will provide their own equipment (though tutors may be given help - see [35]). Institutionally this is a non-cost, but it remains a 'full-system' cost and should be taken into account for comparative costing purposes. Student and tutor equipment needs to be annualized (perhaps over 5 years, though this may be optimistic) [50].

Some systems require non-core staff to provide their own equipment (see assumptions built into [37])

Software The initial cost of common software is bundled in with (capital) machine purchase - but 'specialist' software may need to be purchased. This is a capital cost but it would be unwise to assume that the software will last as long as the computer. Students may well need to budget to upgrade software.

\begin{tabular}{|c|c|c|}
\hline \multirow[t]{3}{*}{ Student/tutor expenses } & \multirow[t]{3}{*}{ Expense } & $\begin{array}{l}\text { Includes any payments to an ISP and/or connection } \\
\text { charges for time online; also needs to cover increased } \\
\text { energy costs. Tutors may have their ISP costs refunded } \\
\text { [35]. }\end{array}$ \\
\hline & & Insurance costs (for equipment) \\
\hline & & Equipment repair costs \\
\hline
\end{tabular}

Opportunity costs

Cost of student time
Opportunity cost for all students, but staff cost for firms
This is a real opportunity cost to employers, and also to the self-employed, who could be doing productive work rather than spending time in training. There is an argument in any cost comparison exercise for placing a value on every student's time (c.f. [25]). It has been suggested that online courses compress the time required to undertake training,

\section{Tuition \\ Tuition}

Staff

Expenses
Payment for teaching students online varies. In some systems permanent full-time staff may do the teaching; in other cases staff may be hired by the hour to teach online. Casual labor and labor substitution is commonplace. 
There is a debate as to whether online teaching takes more or less time (see article).

In a dual mode system, teaching online may be regarded as part of normal duties; or it may be regarded as an additional (new) duty which releases staff from other teaching duties (release time) [35] or it may be regarded as an additional duty for which staff are paid overtime (overload pay) [35].

Institutions may restrict enrolments on online course in order to contain the impact of online teaching on staff time (which has implications for costing exercises looking at the impact on costs of expansion).

\begin{tabular}{ll}
\hline Student/Tutor Helpdesk & Staff costs \\
Staffing & Leach and Smallen [51] estimate that staffing the typical \\
& Helpdesk represents between $7-12 \%$ of the total \\
& central IT staff. Call centers may well have less \\
& expensive front-line staff to handle routine queries, \\
& together with a referral system to faculty where this is \\
& necessary.
\end{tabular}




\section{Appendix 3: Overhead and infrastructure costs}

\begin{tabular}{lll}
\hline $\begin{array}{l}\text { Expenditure descriptor } \\
\begin{array}{l}\text { High level decision making to } \\
\text { embark on online learning }\end{array}\end{array}$ & $\begin{array}{l}\text { Expenditure } \\
\text { category }\end{array}$ & Comments \\
\hline Decision-making & Staff & $\begin{array}{l}\text { Overhead management time }- \text { often difficult to } \\
\text { identify. Much depends on the context and } \\
\text { whether the activity is marginal or central to } \\
\text { management concerns. Development of an IT } \\
\text { strategy requires considerable time and effort [29, } \\
53]\end{array}$ \\
\hline $\begin{array}{lll}\text { Expenses related to high level } \\
\text { decision-making }\end{array}$ & $\begin{array}{l}\text { Expenses/ } \\
\text { consumables }\end{array}$ & $\begin{array}{l}\text { e.g. costs of study tour to existing virtual } \\
\text { universities; costs of consultants brought in to } \\
\text { advise. These costs are difficult to trace where the } \\
\text { decision is marginal to the ongoing concerns of an } \\
\text { institution, but easier to trace if one is setting up a } \\
\text { new institution or department. }\end{array}$ \\
\hline
\end{tabular}

Institutional

evaluation/quality assurance

$\begin{array}{lll}\text { Expenses } & \text { Staff cost } & \text { E.g. survey costs, report production and }\end{array}$

Expenses/ dissemination costs, etc.

consumables

\begin{tabular}{lll}
\hline Web-site development costs & Likely to be expensive [49] \\
Overall web site costs & $\begin{array}{l}\text { General } \\
\text { comment }\end{array}$
\end{tabular}

\begin{tabular}{lll}
\hline $\begin{array}{l}\text { Web site development staffing } \\
\text { costs (e.g.) }\end{array}$ & Staff cost & $\begin{array}{l}\text { As suggested in [49], staff costs put into web site } \\
\text { development can be significant. }\end{array}$ \\
- Internet specialists & &
\end{tabular}

- Internet specialists

- Graphics/Internet designer

\begin{tabular}{|c|c|c|}
\hline $\begin{array}{l}\text { Staff computers purchase } \\
\text { Software purchase }\end{array}$ & Capital & $\begin{array}{l}\text { Annualise: most commentators use a } 5 \text {-year life } \\
\text { but this may be optimistic. Typical replacement } \\
\text { cycles in US colleges are between } 3 \text { and } 5 \text { years } \\
{[50] \text {. Software may well have an even shorter life. }}\end{array}$ \\
\hline
\end{tabular}

Staff computers repair $\quad$ Expense

\begin{tabular}{lll}
\hline $\begin{array}{l}\text { Web site implementation } \\
\text { General comment }\end{array}$ & $\begin{array}{l}\text { All cost } \\
\text { categories }\end{array}$ & $\begin{array}{l}\text { Generally the full costs of networked services are } \\
\text { not as yet reflected in the annual operating } \\
\text { budgets of organisations, nor are the costs of } \\
\text { maintaining services }\end{array}$
\end{tabular}

Domain name registration Expense

\begin{tabular}{lll}
\hline $\begin{array}{l}\text { Learning Platform Software } \\
\text { License Fees, and } \\
\text { Upgrade costs }\end{array}$ & Capital & Initial cost \\
& Expense & $\begin{array}{l}\text { Annual update at 10\% [25]. Wide variation in the } \\
\text { cost of licenses from Canadian } \$ 3000-175,000\end{array}$ \\
{$[25]$.}
\end{tabular}


system cost studies suggest wide variation in costs allowed for this.

Network costs - access to $\quad$ Expense
Internet

\section{Buildings and accommodation} (main offices etc.)

A range of costs involved here Capital or including:

Purchase of land

expense

Construction of a new building

Purchase of an existing building

Refurbishment cost of an

existing building

Rental of office accommodation

\footnotetext{
Buildings and accommodation: running costs including rates (i.e. tax levied on the occupation or ownership of land); buildings and contents insurance; utilities (heat, light, water, power, waste disposal); telephone, fax, etc (rental and usage); repairs and maintenance (direct labor plus materials, or outside contractor charges plus management and supervision costs); grounds and gardens; porters; security; cleaning; management and supervision of all these activities
}

\author{
Stocks, \\ Supplies, \\ Consumables \\ and Expenses
These items are either treated as a general overhead expense, or they are charged to particular departments and treated as a departmental expense. Where they are treated as a general overhead expense, some proxy measure may be used to allocate these costs out to departments (e.g. floor space measures, staffing \\ levels)
}

Capital costs need to be annualized. The actual construction cost of a building may be known (but if in the past, should be brought up to present day values), or may be estimated (using the average building cost per square meter/foot for that type of building). The lifetime of buildings is debatable but probably ranges from 5-10 years (temporary buildings) to 50 (permanent buildings).

Smaller projects utilising a few rooms within an organisation might be charged a proportion of the total building costs, based on floor space as a proportion of all space. Alternatively a shadow rental cost could be used, based on commercial rents payable in the area.

Generally space costs are driven by the number of staff working from an office complex, together with space for consultants' workstations; homebased workers will use their own space and in that sense not be part of the space calculation.

However, any comparative study should put a cost on home office space.

\footnotetext{
Intranet cost (main offices)

Start-up capital costs (new PCs, Capital network connections for PCs not currently networked, servers and server software, and software applications whether developed in-house or purchased
}

In systems where online learning is only part of the activity some kind of measure will need to be used to allocate a proportion of the general expenses to the online operation.
An intranet may exist but if not capital equipment costs will be incurred establishing it.

Capital costs will need to be annualized. Leach and Smallen [51] found the typical annualisation period to be 5 to 6 years. However, some of the equipment will be subject to annual upgrading, repair, etc. Software applications are likely to have a shorter life and require upgrading more 
regularly.

Start-up costs (e.g. design consultancy costs, costs of inhouse designers and technical support staff, training costs)
Revenue expenses and staff costs

On-going revenue costs (e.g. editorial and design staff, technical personnel, etc., onRevenue staffing costs going consultancy, promotion, training, maintenance of bespoke applications)

\section{Furniture (main offices)}

Furniture

Capital

Distinguish between the cost of dedicated staff workstations (linked to staff numbers) and the costs of shared workstations/common furniture spread across staff.

\section{Local center/training center}

Accommodation
Expense Systems that provide telelearning centers will (conceivably a incur accommodation costs - with the capital cost) accommodation usually rented, though purchase is a possibility. There will also be the associated running and maintenance costs of each center in the system.

A telecenter will need desks, chairs, storage cupboards, shelving (for a small library) as well as equipment (server, several PCs, printer(s), fax, photocopier, telephone, etc.) - together with the associated wiring.

\begin{tabular}{|c|c|c|}
\hline Staffing & Staff cost & Technical and security staff \\
\hline Consumables and expenses & $\begin{array}{l}\text { Consumables } \\
\text { and expenses }\end{array}$ & \\
\hline Equipment replacement & $\begin{array}{l}\text { Capital (funded } \\
\text { from revenue) }\end{array}$ & $\begin{array}{l}\text { Simple depreciation does not allow sufficient } \\
\text { money for replacement of equipment. }\end{array}$ \\
\hline Insurance of equipment & Expense & \\
\hline $\begin{array}{l}\text { Digitized courseware / general } \\
\text { library - development and } \\
\text { running costs }\end{array}$ & & See [28] for a case study \\
\hline $\begin{array}{l}\text { Equipment - initial purchase } \\
\text { and replacement }\end{array}$ & Capital & $\begin{array}{l}\text { e.g. computer, scanner, software. Costs need to be } \\
\text { annualized. }\end{array}$ \\
\hline Maintenance of equipment & Expense & \\
\hline $\begin{array}{l}\text { Technical staff to create and } \\
\text { maintain record - document } \\
\text { scanning, indexation, etc., and } \\
\text { to maintain system/equipment }\end{array}$ & Staff costs & Salary and on-costs (benefits) \\
\hline
\end{tabular}

\section{Marketing costs}

Marketing staff

Staff costs

Salary and on-costs (benefits) 


\begin{tabular}{lll}
\hline Non-staff costs & $\begin{array}{l}\text { Expenses/ } \\
\text { consumables }\end{array}$ \\
\hline $\begin{array}{l}\text { Shared central costs } \\
\begin{array}{l}\text { E.g. costs of personnel, } \\
\text { purchasing, financial } \\
\text { management, accounting, and } \\
\text { audit, etc. }\end{array}\end{array} \quad \begin{array}{ll}\text { All revenue cost } \\
\text { types }\end{array}$ & $\begin{array}{l}\text { In dual mode systems, a proportion of these } \\
\text { overhead costs would need to be apportioned to } \\
\text { the networked learning 'enterprise', and the rest } \\
\text { to other business objectives. }\end{array}$ \\
\hline
\end{tabular}

\section{ABOUT THE AUTHOR}

Greville Rumble is Professor of Distance Education Management at The Open University in the United Kingdom, and Editor of the journal Open Learning. Originally a historian with a BA and research-based MA from the University of Kent at Canterbury, his PhD from The Open University was on the costs and economics of open and distance learning. He has published extensively on the planning, management and costs of distance education, and has worked professionally in over 40 countries. 